\title{
Improvement of myocardial perfusion reserve detected by cardiovascular magnetic resonance after direct endomyocardial implantation of autologous bone marrow cells in patients with severe coronary artery diseases
}

\author{
Carmen Wing-Sze Chan', Yok-Lam Kwong ${ }^{2}$, Raymond Y Kwong ${ }^{3}$, Chu-Pak Lau' ${ }^{1}$, Hung-Fat Tse ${ }^{1,2^{*}}$
}

\begin{abstract}
Background: Recent studies suggested that bone marrow (BM) cell implantation in patients with severe chronic coronary artery disease (CAD) resulted in modest improvement in symptoms and cardiac function. This study sought to investigate the functional changes that occur within the chronic human ischaemic myocardium after direct endomyocardial BM cells implantation by cardiovascular magnetic resonance (CMR).

Methods and Results: We compared the interval changes of left ventricular ejection fraction (LVEF), myocardial perfusion reserve and the extent of myocardial scar by using late gadolinium enhancement CMR in 12 patients with severe CAD. CMR was performed at baseline and at 6 months after catheter-based direct endomyocardial autologous BM cell $(n=12)$ injection to viable ischaemic myocardium as guided by electromechanical mapping. In patients randomized to receive $\mathrm{BM}$ cell injection, there was significant decrease in percentage area of peri-infarct regions $(-23.6 \%, P=0.04)$ and increase in global $\operatorname{LVEF}(+9.0 \%, P=0.02)$, the percentage of regional wall thickening $(+13.1 \%, P=0.04)$ and MPR $(+0.25 \%, P=0.03)$ over the target area at 6 -months compared with baseline.

Conclusions: Direct endomyocardial implantation of autologous BM cells significantly improved global LVEF, regional wall thickening and myocardial perfusion reserve, and reduced percentage area of peri-infarct regions in patients with severe CAD.
\end{abstract}

\section{Background}

Recent clinical studies [1-5] suggest that direct implantation of autologous bone marrow (BM) cells into the ischaemic myocardium improves symptoms and exercise capacity and increases left ventricular (LV) function in patients with severe coronary artery disease (CAD). Despite the absence of trans-differentiation of transplanted BM cells into ischaemic myocardium, improvement in LV function is observed in experimental studies [6,7]. Indeed, emerging evidences from experimental studies indicate than BM cells might exert their benefit via paracrine effects to induce angiogenesis in

\footnotetext{
* Correspondence: hftse@hkucc.hku.hk

'Cardiology Division, Department of Medicine, University of Hong Kong, Queen Mary Hospital, Hong Kong
}

(c) 2010 Chan et al; licensee BioMed Central Ltd. This is an Open Access article distributed under the terms of the Creative Commons Attribution License (http://creativecommons.org/licenses/by/2.0), which permits unrestricted use, distribution, and reproduction in any medium, provided the original work is properly cited. ited data on the functional effects of direct BM cells implantation in human [1,2]. Advances in cardiovascular magnetic resonance (CMR) allow non-invasive assessment and serial monitoring of myocardial perfusion by capturing the first-pass perfusion of a bolus of gadolinium injection [10-13]. Furthermore, the use of late gadolinium enhancement (LGE) CMR can identify and quantity the amount of heterogeneous zone of viable and nonviable peri-infarct myocardium, which has been shown to be a powerful predictor for mortality in post myocardial infarction patients [14]. In this study, we sought to investigate the changes in myocardial function, perfusion and myocardial scar using CMR imaging in patients with severe CAD following direct endomyocardial BM cells implantation. 


\section{Methods \\ Study Population}

Among those 28 patients enrolled into a Phase I-II randomized PROTECT-CAD trial to evaluate the safety and feasibility of using a catheter-based intramyocardial autologous BM cells implantation [15], we performed a subgroup analysis in 12 patients recruited in Hong Kong who had received BM cells injection in whom detailed CMR was performed using the same imaging protocol. The details of inclusion, exclusion criteria and study protocol have been reported previously [15]. As reported previously [15], patients treated with BM cell injection had significant improvement in global and regional LV function as measured by CMR compared with controls. This is a post-hoc exploratory analysis to study the changes in CMR parameters in patients treated with BM injections which were not included in the predefined analysis of the PROTECT-CAD trial.

\section{Study Protocol}

In brief, all patients enrolled into PROTECT-CAD trial were suffered from severe CAD with reversible perfusion defects detected by single-photon emission computed tomography and had no other option for conventional revascularization therapies. All patients gave informed consent, and the protocol was approved by the institutional review boards. The study population was randomized to receive direct intramyocardial injection of either BM cells (BM group) or autologous plasma (controls) into chronic ischemic myocardium as guided by electromechanical mapping in 2:1 ratio [15].

In this sub-study, all patients were randomized to the BM group. As reported previously [1,15], mononuclear cells at a concentration of $1 \times 10^{7}$ cells per ml were prepared by Ficoll density gradient centrifugation of autologous BM cells harvested from the right iliac crest in each patient. The cell viability was $>95 \%$ and intramyocardial injection was performed immediately after preparation ( 3 hours after harvesting). All patients underwent non-fluoroscopic LV electromechanical mapping (NOGA system, Biosense-Webster) to identify targeted ischaemic myocardium which was matched SPECT and CMR perfusion imaging [1-5,15]. At each targeted ischaemic region, injections of $0.1 \mathrm{ml}$ of mononuclear cell suspension were delivered as guided by electromechanical mapping [15].

\section{CMR Protocol Cine CMR}

CMR was performed at baseline and at 6 months after catheter-based direct endomyocardial autologous BM cell, and within one week after the single-photon emission computed tomography examination. All patients were examined in the supine position with a $1.5 \mathrm{~T}$ system (CV/I, General Electric, Milwaukee, Wisconsin), using a four-element phased-array cardiac coil. All images were obtained during repeated breath-holds. Cine images were performed in multiple parallel shortaxis planes covering the entire LV using an ECG-gated segmented $\mathrm{K}$ space, steady state free precession pulse sequence as previously reported [14-16].

\section{Adenosine First Pass Perfusion CMR}

An intravenous bolus of $0.05 \mathrm{mmol} / \mathrm{kg}$ gadoliniumDTPA (Magnevist, Schering) was administered at a rate of $5 \mathrm{ml} / \mathrm{s}$ by a power injector 4 minutes after continuous adenosine infusion at $140 \mathrm{mg} / \mathrm{kg} / \mathrm{min}$. All patients were under continuous blood pressure, pulse oximetry and electrocardiogram monitoring. First-pass perfusion imaging was performed simultaneously with contrast injection for the first 30 to 60 heart beats, using a saturation recovery interleaved fast gradient echo-echo planar pulse sequence at three short-axis left ventricular level (basal, mid ventricular and apical) as previously reported [14-16]. After a twenty minute waiting period for equilibration of the contrast agent within the myocardium, the resting first pass perfusion imaging using the same imaging parameters and same slice locations were acquired.

\section{Late Gadolinium Enhancement (LGE) CMR}

According to a previously described inversion recovery pulse sequence (repetition time, $4.8 \mathrm{~ms}$; echo time, 1.4 ms; in-plane spatial resolution between $1.5-1.8 \mathrm{~mm}$ and 1.8-2.1 mm)[17], LGE images at matching cine-image slice locations were required 10 to 15 minutes after cumulative dose of $0.15 \mathrm{mmol} / \mathrm{Kg}$ intravenous gadolinium-DTPA administration. The inversion time (250 to $300 \mathrm{~ms}$ ) was optimized to null the normal myocardium and adjusted the views per segment and trigger delay according to the patient's heart rate.

\section{CMR Image Analysis}

All images were reviewed and analyzed off-line with specialized post-processing software (Cinetool version 3.9.8, General Electric Healthcare) by two investigators (WSC and RYK). Analysis and interpretation of all imaging data were blinded to the clinical data and outcome. The LV volume measurement, calculation of ejection fraction and regional wall thickening were analyzed using the same technique which was reported in the previous study $[18,16]$. The LV volumes were determined by planimetry at the end-systolic and end-diastolic frame, and the LV myocardial mass was calculated by subtracting the endocardial volume from the epicardial volume at end diastole and then multiplying by the tissue density $(1.05 \mathrm{~g} / \mathrm{ml})$.

\section{First-Pass Perfusion Analysis}

All first-pass perfusion images were analyzed in shortaxis planes according to the standardized myocardial segmentation and nomenclature for tomographic 
imaging of the heart [19], with each equiangular segment per slice assigned to a coronary artery territory. For perfusion analysis, the endocardial and epicardial contours were manually traced and corrected for displacement during breathing. The myocardial signal intensity and arterial input function measured in the basal LV slice were determined for all time points. The myocardial blood flow was determined by deconvolution of myocardial signal intensity curves with an arterial input function measured in the LV blood pool by using the Fermi model and expressed in $\mathrm{mL} / \mathrm{min} / \mathrm{gm}[20,21]$. The myocardial reserve was calculated from the ratio of myocardial blood flow during adenosine infusion to myocardial blood flow at rest and used as an index for the detection of any changes of myocardial perfusion after BM injections.

\section{Infarct and Peri-infarct Size Analysis}

The endocardial and epicardial contours on delayed enhancement images were traced manually (Figure 1). By using a semiautomatic detection algorithm, a signalintensity threshold of 2 standard deviations (SDs) above a reference remote myocardial region on the same slice was applied to quantify the total infarct mass $\left(\mathrm{MDE}_{\text {total }}\right)$ $[10,22,23]$. It was further partitioned into the strongly enhanced core infarct mass $\left(\mathrm{MDE}_{\text {core }}\right)$ and the periinfarct mass $\left(\mathrm{MDE}_{\text {peri-infarct }}\right)$ based on signal-intensity thresholds of 3 SDs and 2 to 3 SDs above the remote reference segment, respectively. Infarct size (\%MDE was expressed as a percentage of LV mass. Furthermore, normalized $\mathrm{MDE}_{\text {peri-infarct }}$ and $\mathrm{MDE}_{\text {core }}$ as percentages of the $\mathrm{MDE}_{\text {total }}$ were calculated as previously described [14].

\section{Statistical Analysis}

Data are reported as means \pm 1 standard derivation. Comparisons between paired variables were performed using Student's t test, with a significance level of $\mathrm{P}<$ 0.05 . All statistical analyses were conducted with SPSS version 13.

\section{Results}

The baseline characteristics of the study population are shown in Table 1. A total of 190 percutaneous catheterbased endomyocardial injections to 21 ischaemic regions (inferior $=6$, lateral $=5$, septal $=5$, and anterior $=5$ ) as guided by the electromechanical mapping were performed in 12 patients without any acute complication. On average, $16 \pm 4$ (range 9-23) injections per patient were performed.

\section{CMR Analysis}

There was no significant difference in terms of the haemodynamic conditions of patients at 6 months compared with baseline. Compared with baseline, there were significant improvement in LV ejection fraction (51 \pm
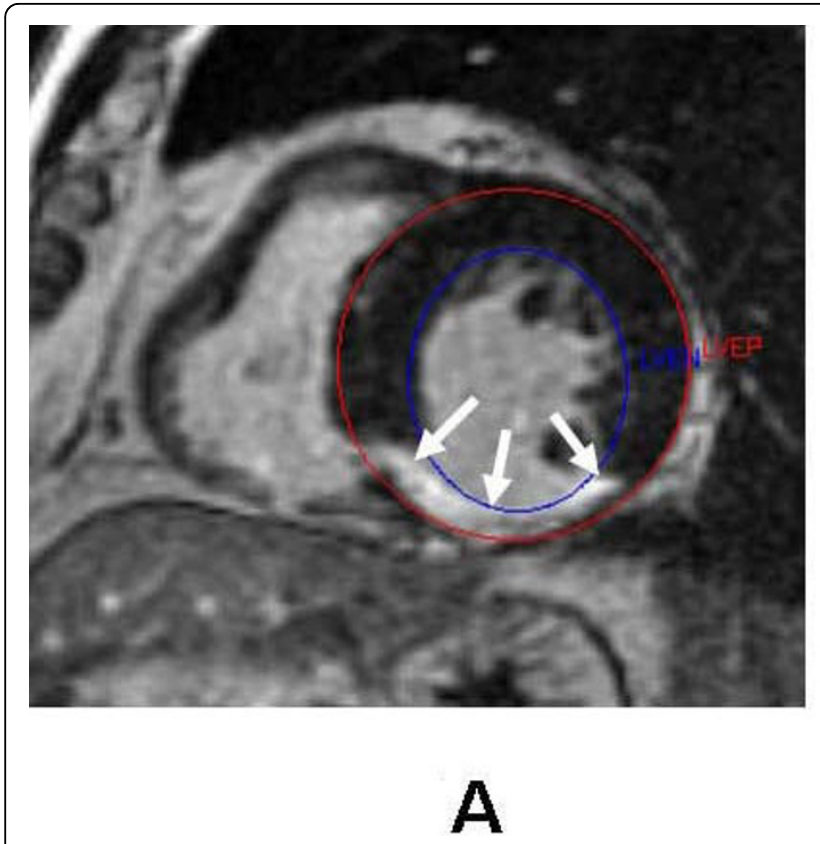
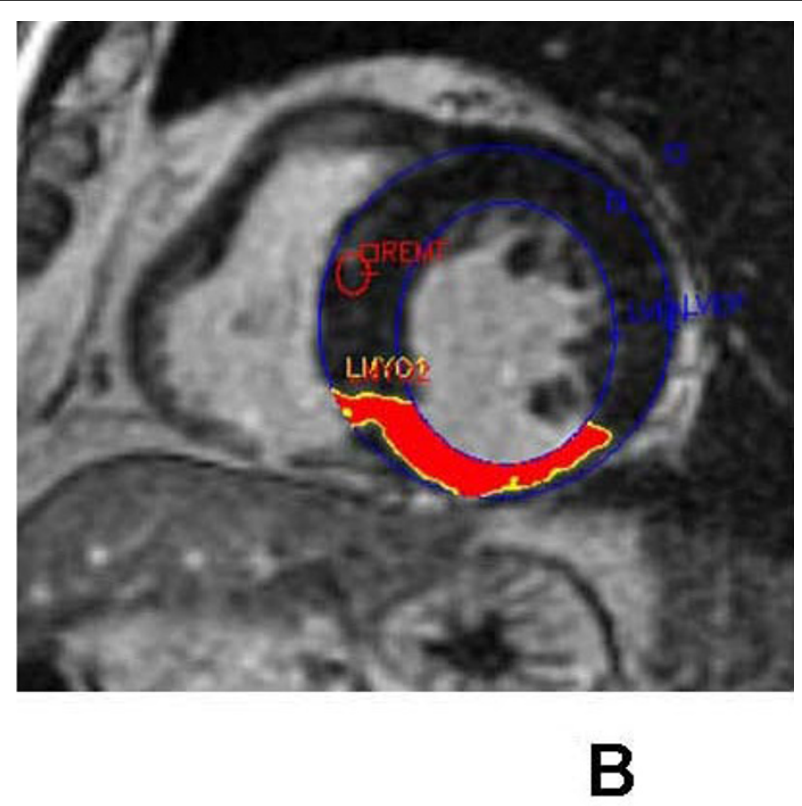

Figure 1 (A) The endocardial (LVEN) and epicardial (LVEP) borders at the end diastole of delay enhancement image were trace manually. The white arrows indicating the extension of transmural myocardial infarction shown up as area of LGE. (B) A computer-assisted

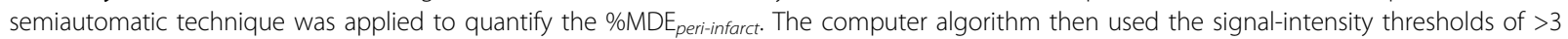
SDs and 2 to 3 SDs above the normal myocardial segment (REMT) to delineate the infarct core (LYMO1- red region) and peri-infarct area (LYMO 2-yellow region) respectively. 
Table 1 Baseline characteristics

\begin{tabular}{|c|c|}
\hline & $N=12$ \\
\hline Age, years & $66 \pm 9$ \\
\hline Men, n (\%) & $9(75)$ \\
\hline Diabetes mellitus, n (\%) & $7(58)$ \\
\hline Hyperlipidaemia, n (\%) & $\begin{array}{c}12 \\
(100)\end{array}$ \\
\hline Hypertension, n (\%) & $10(83)$ \\
\hline Current cigarette smoker, n (\%) & $6(50)$ \\
\hline Percutaneous coronary intervention, $\mathrm{n}(\%)$ & $10(83)$ \\
\hline Coronary artery bypass surgery, $\mathrm{n}(\%)$ & $7(58)$ \\
\hline \multicolumn{2}{|l|}{ Injected treatment site, $\mathrm{n}(\%)$ : } \\
\hline Inferior wall & $7(32)$ \\
\hline Lateral wall & $2(9)$ \\
\hline Anterior wall & $5(23)$ \\
\hline Septal wall & $8(36)$ \\
\hline \multicolumn{2}{|l|}{ Medication at baseline, $\mathrm{n}(\%)$} \\
\hline $\begin{array}{l}\text { Angiotensin-converting enzyme inhibitors or angiotensin- } \\
\text { receptor blockers }\end{array}$ & $6(50)$ \\
\hline Aspirin and/or clopidogrel & $\begin{array}{c}16 \\
(100)\end{array}$ \\
\hline$\beta$ - blockers & $\begin{array}{c}12 \\
(100)\end{array}$ \\
\hline Calcium channel blockers & $8(67)$ \\
\hline Nitrates & $\begin{array}{c}12 \\
(100)\end{array}$ \\
\hline Statins & $\begin{array}{c}16 \\
(100)\end{array}$ \\
\hline \multicolumn{2}{|l|}{ Medication at 6 months, $\mathrm{n}(\%)$} \\
\hline $\begin{array}{l}\text { Angiotensin-converting enzyme inhibitors or angiotensin- } \\
\text { receptor blockers }\end{array}$ & $6(50)$ \\
\hline Aspirin and/or clopidogrel & $\begin{array}{c}16 \\
(100)\end{array}$ \\
\hline$\beta$ - blockers & $\begin{array}{c}12 \\
(100)\end{array}$ \\
\hline Calcium channel blockers & $7(58)$ \\
\hline Nitrates & $11(92)$ \\
\hline Statins & $\begin{array}{c}16 \\
(100)\end{array}$ \\
\hline
\end{tabular}

$10 \%$ versus $56 \pm 9 \%, P=0.02)$ and regional $\mathrm{LV}$ wall thickening over the targeted regions $(48.1 \pm 10.2 \%$ versus $53.4 \pm 8.6 \%, P=0.03)$ at 6 -month. However, there were no significant changes in the LV end diastolic volume $(150 \pm 33 \mathrm{ml}$ versus $146 \pm 30 \mathrm{ml}, P=0.70)$ and $\mathrm{LV}$ mass $\left(99 \pm 28 \mathrm{gm} / \mathrm{m}^{2}\right.$ versus $95.6 \pm 28.5 \mathrm{gm} / \mathrm{m}^{2}, P$ $=0.75$ ) between 6-month and baseline.

\section{Changes in Myocardial Perfusion Reserve}

Table 2 shows the values of myocardial blood flow at rest and during adenosine stress at the targeted and non-targeted region at baseline and 6 month follow-up. At baseline, the myocardial perfusion reserve in all patients was significantly lower at the targeted regions as compared to non-targeted regions $(1.2 \pm 0.2$ versus $2.1 \pm 0.6, P=0.002$ ), suggestive of significant myocardial ischaemia at the targeted regions.

As shown in Figure 2, the myocardial perfusion reserve at the targeted regions after BM cell injection was significantly increased at 6-month compared with baseline $(1.2 \pm 0.3$ versus $1.5 \pm 0.4, P=0.03)$. Nevertheless, there was no change in myocardial perfusion reserve at the non-targeted regions between 6-month and baseline $(2.1 \pm 0.6$ versus $2.3 \pm 0.6, P=0.20)$.

\section{Tissue Characterization by LGE}

LGE was present in all patients, consistent with prior myocardial infarction. $75 \%$ patients had $<50 \%$ transmural infarction while the remaining patients had 50 $75 \%$ transmural infarction. Compared with baseline, there was an insignificant modest reduction in the \% $\mathrm{MDE}_{\text {total }}$ at 6 -month $(-23 \%, P=0.06)$ after BM cell injection. Nevertheless, there was a significant decrease in $\% \mathrm{MDE}_{\text {peri-infarct }}$ at 6-month as compared with baseline $(-38 \%, P=0.04$, Figure 3$)$. However, there was no significant difference in the transmural extension of LGE $(P=0.8)$

\section{Discussion}

The results of this study demonstrate that direct intramyocardial implantation of BM cells was associated with increased myocardial perfusion reserve and regional LV wall thickening at the targeted ischemic regions. Furthermore, there was a reduction in the extent of ischemic peri-infarct area detected by CMR, without any significant decrease in the extent of core infarct area after BM cells injection. Taken together, these CMR findings suggest that BM cells implantation improve myocardial perfusion reserve and reduce ischaemic peri-infarct region in human ischemic myocardium, which subsequently contribute to an improvement in regional LV function.

In this study, the mean myocardial perfusion reserve in the targeted ischaemic regions was significantly lower

Table 2 Myocardial blood flow at rest and during adenosine stress at the targeted and non-targeted region at baseline and at 6 months after bone marrow cell injection

\begin{tabular}{lllll}
\hline & & Baseline & & \multicolumn{1}{c}{ month follow-up } \\
\cline { 2 - 5 } & $\begin{array}{l}\text { Rest } \\
\mathbf{m L} / \mathbf{m i n} / \mathbf{g m}\end{array}$ & $\begin{array}{l}\text { Adenosine Stress } \\
\mathbf{m L} / \mathbf{m i n} / \mathbf{g m}\end{array}$ & $\begin{array}{l}\text { Rest } \\
\mathrm{mL} / \mathrm{min} / \mathbf{g m}\end{array}$ & Adenosine Stress $\mathbf{m L} / \mathbf{m i n} / \mathbf{g m}$ \\
\hline Targeted regions & $0.67 \pm 0.17$ & $0.83 \pm 0.16$ & $0.75 \pm 0.3$ & $1.12 \pm 0.5$ \\
Non-targeted regions & $0.97 \pm 0.9$ & $2.01 \pm 0.7$ & $1.01 \pm 0.5$ & $2.3 \pm 0.7$ \\
\hline
\end{tabular}



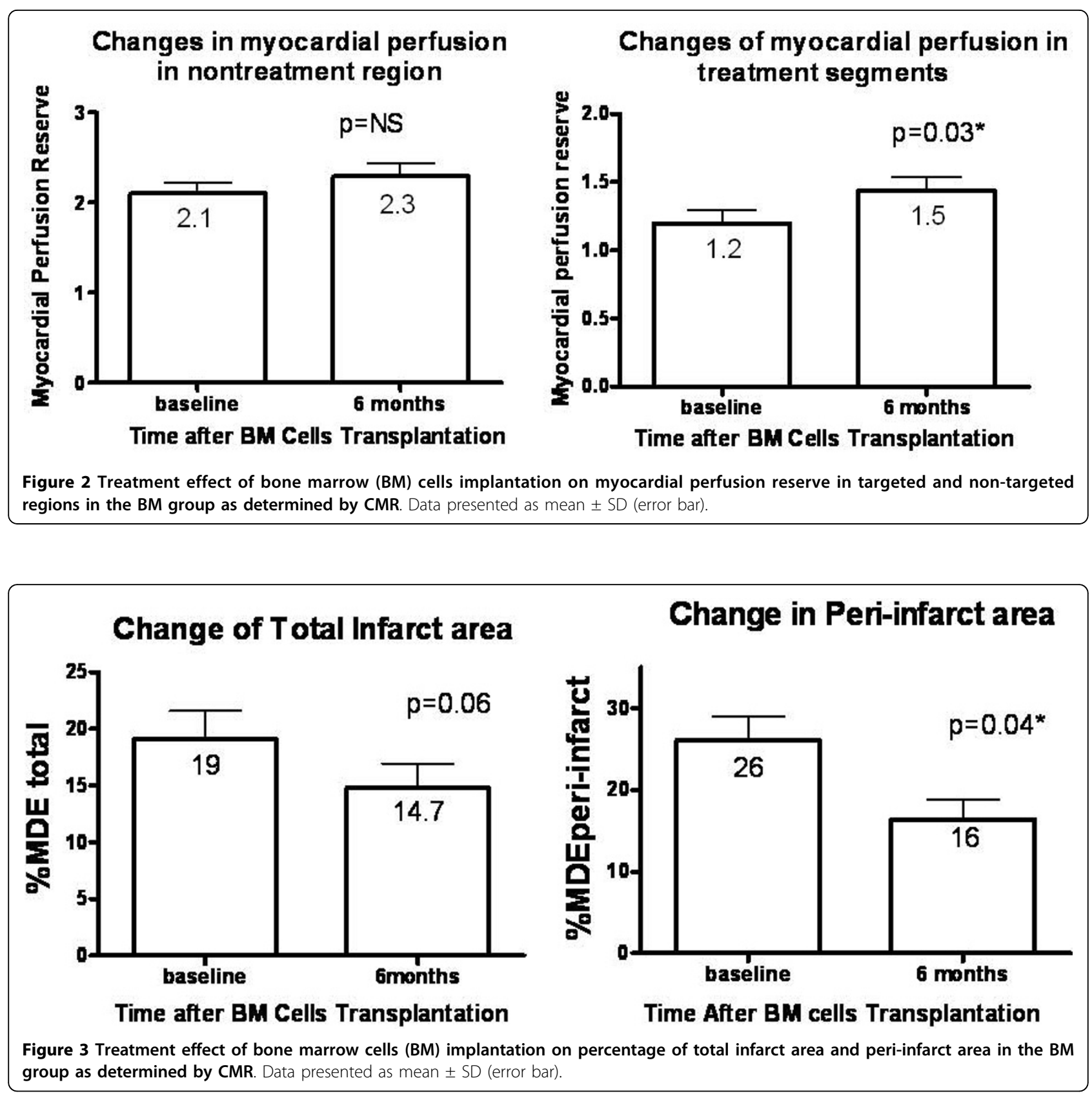

than the non-targeted regions, indicating that the targeted regions have more tissue ischaemia at baseline. The improvement in myocardial perfusion reserve was related to an increase in peak flow rather than a decrease in baseline flow, suggesting enhancement of stress induced myocardial blood flow after BM cell implantation. This postulation is further evidenced by the reduction in the extent of ischaemic myocardium at 6-month after BM cells implantation compared with baseline.

Furthermore, the lack of significant reduction in core infarct area after BM cells implantation indicates the lack of significant myocardial regeneration over the scar area. These results are consistent with the findings in recent experimental studies which showed limited capability of BM cells to trans-differentiate into cardiomyocytes and continued to differentiate along the hematopoietic lineage after transplantation $[5,6,24]$. However, an improvement in LV function was consistently observed in small $[5,6]$ and large animal studies $[7,8,25,26]$ after BM cells transplantation. Experimental studies have suggested that the majority of the benefit effect of BM cells implantation might exert via paracrine mechanisms with secretion of various angiogenic 
cytokines, such as vascular endothelial growth factor to induce angiogenesis in myocardial ischemia $[8,25,26]$. Nevertheless, it remains unclear whether similar paracrine mechanisms contribute to the improvement in myocardial perfusion reserve as observed in the present study.

\section{Study Limitations}

First, a small sample size of this study is a limitation as only patients with detailed CMR examination using the same protocol and machine were included in this analysis. Therefore, our results need to be confirmed by larger, prospective, randomized studies. Second, although the cutoff of remote +2 SD for the entire infarct has been validated in previous studies and currently being practicing in daily clinical application, future studies are still needed to validate the used a pre-specified, arbitrary signal intensity threshold (remote+ $3 \mathrm{SD}$ ) above the remote myocardium to delineate the core infarct on LGE. Final, whether the treatment effects of BM cells implantation noted after 6 months are sustained over time needs to be studied.

\section{Conclusion}

In conclusion, our data from CMR provide insights into the potential functional effects of catheter-based direct intramyocardial delivery of BM cells in the chronic human ischemic myocardium.

\section{Acknowledgements}

This study is supported Sun Chieh Yeh Heart Foundation Fund, S.K. Yee Medical Foundation Grant (Project No. 203217), and The Research Grants Council of Hong Kong (HKU 7357/02M). The sponsors of the study had no role in study design, data collection, data analysis, data interpretation, or writing of the report.

\section{Author details}

'Cardiology Division, Department of Medicine, University of Hong Kong, Queen Mary Hospital, Hong Kong. ${ }^{2}$ Haematology Division, Department of Medicine, the University of Hong Kong, Queen Mary Hospital, Hong Kong. ${ }^{3}$ Cardiac Magnetic Resonance Imaging, Cardiovascular Division, Brigham and Women's Hospital, Harvard Medical School, Boston, USA.

\section{Authors' contributions}

WSC and RYK were responsible for CMR study design, reading, data analysis and manuscript preparation. HFT, YLK and CPL were responsible study design, patients recruitment and procedure, and manuscript preparation.

\section{Competing interests}

The authors declare that they have no competing interests.

Received: 7 January 2009

Accepted: 25 January 2010 Published: 25 January 2010

\section{References}

1. Tse HF, Kwong YL, Chan JK, Lo G, Ho CL, Lau CP: Angiogenesis in ischaemic myocardium by intramyocardial autologous bone marrow mononuclear cell implantation. Lancet 2003, 361:47-49.

2. Perin EC, Dohmann HF, Borojevic R, Silva SA, Sousa AL, Mesquita CT, Rossi MI, Carvalho AC, Dutra HS, Dohmann HJ, Silva GV, Belem L, Vivacqua R, Rangel FO, Esporcatte R, Geng YJ, Vaughn WK, Assad JA,
Mesquita ET, Willerson JT: Transendocardial, autologous bone marrow cell transplantation for severe, chronic ischemic heart failure. Circulation 2003, 107:2294-2302.

3. Fuchs $S$, Satler LF, Kornowski R, Okubagzi P, Weisz G, Baffour R, Waksman R, Weissman NJ, Cerqueira M, Leon MB, Epstein SE: Catheter-based autologous bone marrow myocardial injection in no-option patients with advanced coronary artery disease. A feasibility study. J Am Coll Cardiol 2003, 41:1721-1724.

4. Briguori C, Reimers B, Sarais C, Napodano M, Pascotto P, Azzarello G, Bregni M, Porcellini A, Vinante O, Zanco P, Peschle C, Condorelli G, Colombo A: Direct intramyocardial percutaneous delivery of autologous bone marrow in patients with refractory myocardial angina. Am Heart J 2006, 151:674-80.

5. Beeres SL, Bax JJ, Kaandorp TA, Zeppenfeld K, Lamb HJ, Dibbets-Schneider P, Stokkel MP, Fibbe WE, de Roos A, Wall van der EE, Schalij MJ, Atsma DE: Usefulness of intramyocardial injection of autologous bone marrowderived mononuclear cells in patients with severe angina pectoris and stress-induced myocardial ischemia. Am J Cardiol 2006, 97:1326-31.

6. Balsam LB, Wagers AJ, Christensen JL, Kofidis T, Weissman IL, Robbins RC: Haematopoietic stem cells adopt mature haematopoietic fates in ischaemic myocardium. Nature 2004, 428:668-673.

7. Chien KR: Stem cells: lost in translation. Nature 2004, 428:607-8.

8. Kinnaird T, Stabile E, Burnett MS, Shou M, Lee CW, Barr S, Fuchs S, Epstein SE: Local delivery of marrow-derived stromal cells augments collateral perfusion through paracrine mechanisms. Circulation 2004, 109:1543-1549.

9. Tse HF, Siu CW, Zhu SG, Songyan L, Zhang QY, Lai WH, Kwong YL, Nicholls J, Lau CP: Paracrine effects of direct intramyocardial implantation of bone marrow derived cells for enhancement of neovascularization in chronic ischemic myocardium. Eur J Heart Fail 2007, 9:747-753.

10. Kim RJ, Fieno DS, Parrish TB, Harris K, Chen EL, Simonetti O, Bundy J, Finn JP, Klocke FJ, Judd RM: Relationship of MRI delayed contrast enhancement to irreversible injury, infarct age, and contractile function. Circulation 1999, 100:1992-2002.

11. Panting JR, Gatehouse PD, Yang GZ, Jerosch-Herold M, Wilke N, Firmin DN, Pennell DJ: Echo-planar magnetic resonance myocardial perfusion imaging: parametric map analysis and comparison with thallium SPECT. J Magn Reson Imaging 2001, 13:192-200.

12. Al-Saadi N, Nagel E, Gross M, Bornstedt A, Schnackenburg B, Klein C, Klimek W, Oswald H, Fleck E: Noninvasive detection of myocardial ischemia from perfusion reserve based on cardiovascular magnetic resonance. Circulation 2000, 101:1379-83.

13. Friedrich MG, Bluemke DA, Biederman RW, Martin ET, Lansky AJ, Kashanian F, Foo TK, Licato PE, Comeau CR: Myocardial firstpass perfusion magnetic resonance imaging: a multicenter dose-ranging study. Circulation 2004, 110:732-737.

14. Yan AT, Shayne AJ, Brown KA, Gupta SN, Chan CW, Luu TM, Di Carli MF, Reynolds HG, Stevenson WG, Kwong RY: Characterization of the periinfarct zone by contrast-enhanced cardiac magnetic resonance imaging is a powerful predictor of post-myocardial infarction mortality. Circulation 2006, 114:34-39.

15. Tse HF, Thambar S, Kwong YL, Rowlings P, Bellamy G, McCrohon J, Thomas P, Bastian B, Chan JK, Lo G, Ho CL, Chan WS, Kwong RY, Parker A, Hauser TH, Chan J, Fong DY, Lau CP: Prospective randomized trial of direct endomyocardial implantation of bone marrow cells for therapeutic angiogenesis in severe coronary artery diseases. Eur Heart $J$ 2007, 28:2998-3005.

16. Kwong RY, Chan AK, Brown KA, Chan CW, Reynolds GH, Tsang S, Davis RB: Impact of unrecognized myocardial scar detected by cardiac magnetic resonance imaging on event-free survival in patients presenting with signs or symptoms of coronary artery disease. Circulation 2006, 113:2733-2743.

17. Simonetti OP, Kim RJ, Fieno DS, Hillenbrand HB, Wu E, Bundy JM, Finn JP, Judd RM: An improved MR imaging technique for the visualization of myocardial infarction. Radiology 2001, 218:215-223.

18. Alfakih $\mathrm{K}$, Reid $\mathrm{S}$, Jones $\mathrm{T}$, Sivananthan M: Assessment of ventricular function and mass by cardiac magnetic resonance imaging. Eur Radiol 2004, 14:1813-1822.

19. Cerqueria MD, Weissman NJ, Dilsizian V, Jacobs AK, Kaul S, Laskey WK, Pennell DJ, Rumberger JA, Ryan T, Verani MS: Standardized myocardial 
segmentation and nomenclature for tomographic imaging of the heart: A statement for healthcare professionals from the cardiac imaging committee of the council on clinically cardiology of the American Heart Association. Circulation 2002, 105:539-542.

20. Wilke $\mathrm{N}$, Jerosch-Herold $\mathrm{M}$, Wang $\mathrm{Y}$ : Myocardial perfusion reserve: assessment with multisection, quantitative, first-pass MR imaging Radiology 1997, 204:373-84.

21. Muhling OM, Wang Y, Panse P, Jerosch-Herold M, Cayton MM, Wann LS, Mirhoseini MM, Wilke NM: Transmyocardial laser revascularization preserves regional myocardial perfusion: an MRI first pass perfusion study. Cardiovasc Res 2003, 57:63-70.

22. Kim RJ, Wu E, Rafael A, Chen EL, Parker MA, Simonetti O, Klocke FJ, Bonow RO, Judd RM: The use of contrast-enhanced magnetic resonance imaging to identify reversible myocardial dysfunction. N Engl J Med 2000 343:1445-1453.

23. Mahrholdt H, Wagner A, Holly TA, Elliott MD, Bonow RO, Kim RJ, Judd RM: Reproducibility of chronic infarct size measurement by contrastenhanced magnetic resonance imaging. Circulation 2002, 106:2322-2327.

24. Murry CE, Soonpaa MH, Reinecke H, Nakajima H, Nakajima HO, Rubart M, Pasumarthi KB, Virag Jl, Bartelmez SH, Poppa V, Bradford G, Dowell JD, Williams DA, Field $L$ : Haematopoietic stem cells do not transdifferentiate into cardiac myocytes in myocardial infarcts. Nature 2004, 428:664-668.

25. Kamihata H, Matsubara $H$, Nishiue T, Fujiyama S, Amano K, Iba O, Imada T, Iwasaka T: Improvement of collateral perfusion and regional function by implantation of peripheral blood mononuclear cells into ischemic hibernating myocardium. Arterioscler Thromb Vasc Biol 2002, 22:1804-10.

26. Kinnaird T, Stabile E, Burnett MS, Epstein SE: Bone-marrow-derived cells for enhancing collateral development: mechanisms, animal data, and initial clinical experiences. Circ Res 2004, 95:354-63.

doi:10.1186/1532-429X-12-6

Cite this article as: Chan et al: Improvement of myocardial perfusion reserve detected by cardiovascular magnetic resonance after direct endomyocardial implantation of autologous bone marrow cells in patients with severe coronary artery diseases. Journal of Cardiovascular Magnetic Resonance 2010 12:6.

\section{Submit your next manuscript to BioMed Central and take full advantage of:}

- Convenient online submission

- Thorough peer review

- No space constraints or color figure charges

- Immediate publication on acceptance

- Inclusion in PubMed, CAS, Scopus and Google Scholar

- Research which is freely available for redistribution

Submit your manuscript at www.biomedcentral.com/submit
Biomed Central 